\title{
Effect of Soil Grain Size Distribution on the Mechanical Damage of Nonwoven Geotextiles Under Repeated Loading
}

\author{
David Miranda Carlos • José Ricardo Carneiro • \\ Margarida Pinho-Lopes • Maria de Lurdes Lopes
}

Received: 11 December 2014/ Accepted: 16 January 2015/Published online: 3 February 2015

(C) Springer International Publishing AG 2015

\begin{abstract}
Installation processes (which induce mechanical damage) may cause undesirable changes on the properties of geosynthetics, affecting their performance. This work evaluates the effect of mechanical damage on the short-term tensile behaviour of two nonwoven geotextiles (with different masses per unit area). The geotextiles were damaged in laboratory using a standardised procedure and an artificial aggregate (corundum) and eight other soils. The damage induced was characterized using wide-width tensile tests. Results showed reductions of the tensile strength of both geotextiles, which depended on the grain size distribution and uniformity of the soils and on the mass per unit area of the geotextiles. The reduction in tensile strength provoked by corundum was higher than the decreases caused by most of the other soils. The mechanical damage tests also led to a reduction of elongation at maximum load and an increase of stiffness.
\end{abstract}

Keywords Geotextiles - Nonwoven - Mechanical damage $\cdot$ Soils $\cdot$ Tensile properties

D. M. Carlos · J. R. Carneiro $(\square) \cdot$ M. de Lurdes Lopes Department of Civil Engineering, Faculty of Engineering, University of Porto, Rua Dr. Roberto Frias, 4200-465 Porto, Portugal

e-mail: rcarneir@fe.up.pt

\section{Pinho-Lopes}

School of Environment and Technology, University of Brighton, Cockcroft Building, Lewes Road, Brighton BN2 4GJ, UK

M. Pinho-Lopes

Department of Civil Engineering, University of Aveiro, Campus Universitário de Santiago, 3810-193 Aveiro, Portugal

\begin{tabular}{|c|c|}
\hline \multicolumn{2}{|c|}{ Abbreviations } \\
\hline FS & Factor of safety \\
\hline GW-GM & Well-graded gravel with silt and sand \\
\hline GP & Poorly graded gravel \\
\hline ML & Sandy silt \\
\hline SM & Silty sand \\
\hline SP & Poorly graded sand \\
\hline SW & Well-graded sand \\
\hline USCS & Unified soil classification system \\
\hline UV & Ultraviolet \\
\hline
\end{tabular}

\section{List of Symbols}

$C_{C} \quad$ Coefficient of curvature

$C_{U} \quad$ Coefficient of uniformity

$D_{x} \quad$ Effective $\mathrm{x} \%$ grain size

$D_{10} \quad$ Effective $10 \%$ grain size

$D_{30} \quad$ Effective $30 \%$ grain size

$D_{50} \quad$ Effective $50 \%$ grain size

$D_{60} \quad$ Effective $60 \%$ grain size

$D_{\max } \quad$ Maximum particle size

$E_{M L} \quad$ Elongation at maximum load

$R F_{C R} \quad$ Reduction factor associated with creep

$R F_{C B} \quad$ Reduction factor associated with chemical and biological degradation

$R F_{I D} \quad$ Reduction factor associated with installation damage

$R F_{M D} \quad$ Reduction factor associated with mechanical damage

TS Tensile strength

$T S_{D} \quad$ Design tensile strength

\section{Introduction}

The process of installation on site can damage the geosynthetics [1], causing unwanted changes in their physical, 
mechanical and hydraulic properties. The damage that occurs during installation is originated essentially from handling the geosynthetics and from the placement and compaction of backfills over them [2]. For some applications the stresses on the geosynthetics from the installation processes are often higher than those in service and need to be adequately considered in their design [3].

The installation damage typically includes cuts in fibres and other components, formation of holes, abrasion, reduction in mechanical resistance and, in the worst scenario, complete destruction of the materials [4], as well as changes in hydraulic properties. Installation damage may depend on many factors, such as: the characteristics of the geosynthetics, the grain size distribution of the soils, the angularity and thickness of the backfill materials, the compaction energy and the use, or not, of adequate installation procedures [5-7]. Often mechanical damage is associated with installation procedures, which usually cause unwanted changes on the properties of geosynthetics.

In the design of geosynthetics it is common to represent the effect of installation damage by reduction factors. For reinforcement applications, the tensile strength of geosynthetics (TS) is typically affected by a set of reduction factors (Eq. 1) associated with installation damage $\left(R F_{I D}\right)$, creep $\left(R F_{C R}\right)$ and degradation due to chemical and biological processes $\left(R F_{C B}\right)$ and a factor of safety (FS). This enables determining the design strength $\left(T S_{D}\right)$.

$T S_{D}=\frac{T S}{R F_{I D} \times R F_{C R} \times R F_{C B} \times \mathrm{FS}}$

Ideally the reduction factor for installation damage should be determined using field installation damage tests with conditions similar to those of the project (installation method, type of backfill and compaction method) and using a common test protocol [8]. Nevertheless, when such data is not available it is possible to use extrapolations [9] based on existing measurements with different soils for the same geosynthetics, or considering other products within the same product line.

To induce mechanical damage of geosynthetics a standardised laboratory procedure has been developed (ENV ISO 10722-1 [10], which was later updated becoming EN ISO 10722 [11]). Several authors have used this procedure to study installation damage $[12,13]$, while others have tried to correlate it with field conditions (for example [14, 15]). According to Huang and Wang [14], the laboratory test ENV ISO 10722-1 [10] can be modified to adequately simulate field installation damage. For that an aggregate similar to that used in the field should be used and the cyclic load intensity changed. Nevertheless, the laboratory damage tests may not always reproduce field installation conditions or installation damage. Thus, the term mechanical damage is used in this paper.

The present paper focus on changing the soil or aggregate used in the laboratory test EN ISO 10722 [11] and assessing the changes on the short-term tensile properties of two nonwoven geotextiles with different masses per unit area. Besides the synthetic aggregate prescribed in the test standard—corundum, other eight soils with different grain size distributions were used. The main goals of this work included: (1) evaluation of the effect of soil grain size distribution on the mechanical damage suffered by nonwoven geotextiles under repeated loading, (2) comparison of the damage induced by corundum (standardised aggregate) with the damage provoked by other soils, (3) evaluation of the effect of some physical properties (mass per unit area or thickness) in the installation survivability of the nonwoven geotextiles.

\section{Experimental Description}

\section{Geotextiles}

This work studies two nonwoven needle-punched geotextiles (with different masses per unit area) made from UVstabilized polypropylene fibres. The designations used for the geotextiles (G250 and G400) are related with their nominal mass per unit area $\left(250\right.$ and $400 \mathrm{~g} \mathrm{~m}^{-2}$, respectively). The main characteristics of the geotextiles (obtained from standardised laboratory tests) are summarized in Table 1.

The sampling and preparation of test specimens were carried out according to EN ISO 9862 [16]. The specimens (machine direction of production) were cut from positions evenly distributed over the full width and length of the geotextiles (supplied in rolls), but not closer than $100 \mathrm{~mm}$ to the edges. The specimens were kept in a dry and dark place at room temperature until the tests were performed.

Table 1 Main characteristics of the geotextiles (reference specimens)

\begin{tabular}{lcc}
\hline Geotextile & G250 & G400 \\
\hline Mass per unit area $^{\mathrm{a}}\left(\mathrm{g} \mathrm{m}^{-2}\right)$ & $262( \pm 14)$ & $412( \pm 20)$ \\
Thickness $^{\mathrm{b}}(\mathrm{mm})$ & $2.37( \pm 0.10)$ & $3.32( \pm 0.15)$ \\
Tensile strength $^{\mathrm{c}}\left(\mathrm{kN} \mathrm{m}^{-1}\right)$ & $16.00( \pm 1.20)$ & $25.56( \pm 0.97)$ \\
Elongation at maximum load $^{\mathrm{c}}(\%)$ & $70.4( \pm 2.5)$ & $70.9( \pm 4.6)$ \\
\hline
\end{tabular}

\footnotetext{
${ }^{a}$ Determined according to EN ISO 9864 [21]

b Determined according to EN ISO 9863-1 [22]

c Determined according to EN ISO 10319 [19] (machine direction of production)

In brackets are the $95 \%$ confidence intervals
} 
Mechanical Damage Tests

\section{Equipment and Test Method}

The mechanical damage tests were performed in a laboratorial prototype equipment following the specifications of EN ISO 10722 [11]. The equipment was formed by a container (Fig. 1) divided into a lower and an upper box (rigid metal boxes where the geotextile and the soil were placed), a loading plate and a compression machine (full description of the equipment can be found in Lopes and Lopes [17]).

The mechanical damage tests were carried out according to EN ISO 10722 [11]: each specimen of geotextile ( $250 \mathrm{~mm}$ wide and $500 \mathrm{~mm}$ long) was placed between two layers of a synthetic aggregate of sintered aluminium oxide (corundum) and submitted to repeated loading. Additional tests were performed using other soils. The layer placed under the specimen consisted in two sublayers (each $37.5 \mathrm{~mm}$ high) compacted by a flat plate loaded to a pressure of $200 \pm 2 \mathrm{kPa}$, during $60 \mathrm{~s}$, over the whole area of the test container. The layer placed over the specimen consisted in loose soil with $75 \mathrm{~mm}$ high. Each specimen was subjected to dynamic loading (ranging between $5 \pm 0.5$ and $500 \pm 10 \mathrm{kPa}$ ) at a frequency of $1 \mathrm{~Hz}$ and for 200 cycles. Finished the loading, the test was stopped and the specimen was removed carefully from the test container, avoiding additional damage.

\section{Soils}

The mechanical damage tests were performed using the synthetic aggregate defined in EN ISO 10722 [11] (corundum) and with eight additional different soils. These additional soils were chosen to represent materials in contact with geotextiles in a variety of geotechnical

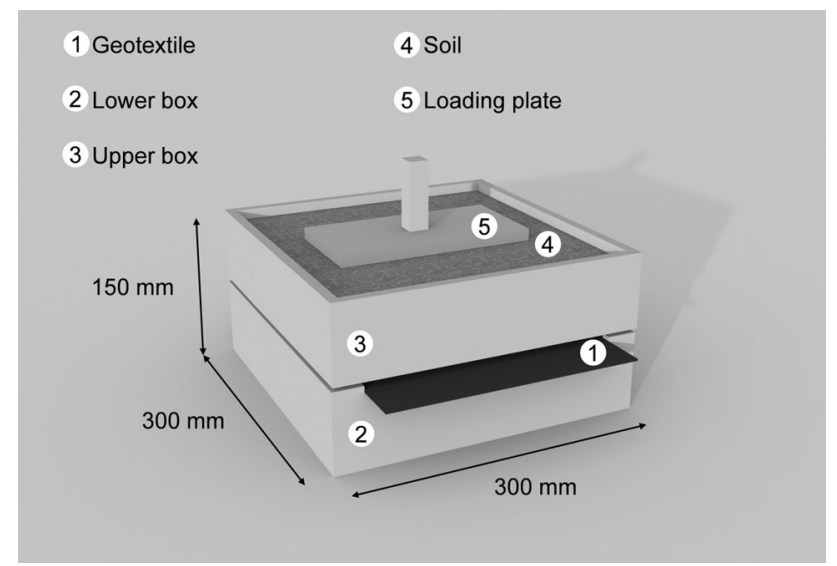

Fig. 1 Schematic representation of the equipment used in the mechanical damage tests structures. For example, silty sands, sands and tout-venant can be used to the construction of reinforced soil walls and slopes, reinforced embankments and pavements (roads, railways or airports); sands can also be used as granular filters. Gravels can be used in drains and filters; silts are commonly used in reinforced slopes and embankments.

The grain size distributions of the soils (evaluated according to ISO/TS 17892-4 [18]) are presented in Fig. 2. The main parameters for the characterisation of the grain size distributions (such as: $D_{x}$-effective x $\%$ grain size, $D_{\max }$-maximum particle size, $C_{U}$-coefficient of uniformity, $C_{C}$-coefficient of curvature) can be found in Table 2.

\section{Evaluation of the Damage}

The mechanical damage induced on the geotextiles was evaluated by visual examination and using wide-width tensile tests (according to EN ISO 10319 [19]). The tensile tests were performed at a speed of $20 \mathrm{~mm} \mathrm{~min}^{-1}$ in a tensile machine from Lloyd Instruments (model LR $50 \mathrm{~K}$ ) equipped with a load cell of $10 \mathrm{kN}$. Each sample was characterised using, at least, five specimens with $200 \mathrm{~mm} \times 200 \mathrm{~mm}$ (length between grips of $100 \mathrm{~mm}$ ). Elongation was measured with a video-extensometer. The mechanical properties determined were the tensile strength $\left(T S\right.$, in $\left.\mathrm{kN} \mathrm{m}^{-1}\right)$ and the elongation at maximum load $\left(E_{M L}\right.$, in $\%$ ).

The $95 \%$ confidence intervals for tensile strength and elongation at maximum load were calculated according to Montgomery and Runger [20]. Some results are expressed in terms of retained tensile strength (in \%). This parameter was obtained by dividing the tensile strength of the damaged samples by the tensile strength of the reference ones (undamaged).

Based on the changes in tensile strength, reduction factors for mechanical damage $\left(R F_{M D}\right)$ were determined. The

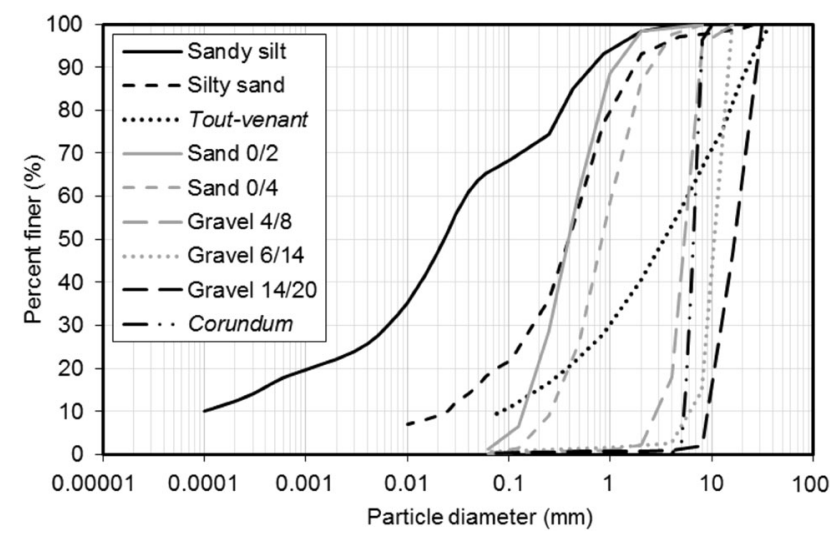

Fig. 2 Grain size distribution of the soils 
Table 2 Characterisation of the grain size distribution of the soils

\begin{tabular}{|c|c|c|c|c|c|c|c|c|c|}
\hline \multicolumn{2}{|l|}{ Soil/aggregate } & \multirow[t]{2}{*}{$\%<0.074 \mathrm{~mm}$} & \multirow[t]{2}{*}{$D_{10}(\mathrm{~mm})$} & \multirow[t]{2}{*}{$D_{30}(\mathrm{~mm})$} & \multirow[t]{2}{*}{$D_{50}(\mathrm{~mm})$} & \multirow[t]{2}{*}{$D_{60}(\mathrm{~mm})$} & \multirow[t]{2}{*}{$D_{\max }(\mathrm{mm})$} & \multirow[t]{2}{*}{$C_{U}$} & \multirow[t]{2}{*}{$C_{C}$} \\
\hline Name & USCS* & & & & & & & & \\
\hline Sandy silt & ML & 66.5 & 0.0001 & 0.007 & 0.023 & 0.038 & 4.8 & 380.0 & 11.1 \\
\hline Silty sand & $\mathrm{SM}$ & 20.0 & 0.025 & 0.188 & 0.394 & 0.549 & 25.4 & 22.0 & 2.6 \\
\hline Sand $0 / 2$ & SP & 2.2 & 0.145 & 0.260 & 0.410 & 0.486 & 8.0 & 3.4 & 1.0 \\
\hline Sand $0 / 4$ & SW & 0.5 & 0.263 & 0.558 & 0.869 & 1.590 & 8.0 & 6.0 & 0.7 \\
\hline Tout-venant & GW-GM & 9.5 & 0.084 & 1.045 & 3.669 & 6.067 & 37.5 & 72.2 & 2.1 \\
\hline Gravel 4/8 & GP & 0.3 & 2.990 & 4.625 & 5.656 & 6.172 & 16.0 & 2.1 & 1.2 \\
\hline Gravel 6/14 & GP & 0.6 & 6.417 & 9.427 & 11.305 & 12.244 & 16.0 & 1.9 & 1.1 \\
\hline Gravel 14/20 & GP & 0.3 & 9.447 & 13.014 & 16.948 & 19.859 & 31.5 & 2.1 & 0.9 \\
\hline Corundum & GP & 0 & 5.323 & 6.017 & 6.661 & 6.913 & 10.0 & 1.3 & 1.0 \\
\hline
\end{tabular}

* Unified soil classification system (ASTM D2487 [23]); Tout-venant-aggregate used in road construction; $M L$ sandy silt; $S M$ silty sand; $S P$ poorly graded sand; $S W$ well-graded sand; $G W-G M$ well-graded gravel with silt and sand; $G P$ poorly graded gravel

reduction factors were obtained as the ratio between the tensile strengths of the reference samples and the damaged ones.

\section{Results and Discussion}

\section{Geotextile G250}

The mechanical damage tests affected geotextile G250 differently, depending on the type of soil used. The visual inspections indicated that the finer confinement soils (sandy silt and silty sand) induced less severe visible changes (no fibre severing, cuts, bruising or abrasion were found). However, for the specimens damaged with these soils the area immediately below the loading plate exhibited some stretching. This is likely to be related to the low bearing capacity of sandy silt and silty sand, which exhibited considerable settlements during loading, inducing permanent deformations to the specimens.

The specimens of geotextile G250 submitted to repeated loading when confined in the sands showed fibre severing and bruising. The contact with coarser soils, namely the three gravels, the tout-venant and the corundum provoked more damage (such as fibre severing, cuts, bruising and abrasion) than the remaining soils. Some stretching of the specimens was observed, but less significant than for the sandy silt and the silty sand.

The tensile properties of geotextile G250 after the mechanical damage tests are presented in Table 3. Figure 3 includes mean curves tensile force-elongation for the reference sample and after mechanical damage with some of the soils considered. The curves omitted were very similar to the ones presented and were removed to make the figure easier to understand.
Table 3 Tensile properties of geotextile G250 after the mechanical damage tests

\begin{tabular}{lll}
\hline Soil & $T S\left(\mathrm{kN} \mathrm{m}^{-1}\right)$ & $E_{M L}(\%)$ \\
\hline Sandy silt & $15.57( \pm 1.08)$ & $59.3( \pm 5.2)$ \\
Silty sand & $15.46( \pm 0.72)$ & $60.8( \pm 5.8)$ \\
Sand 0/2 & $13.80( \pm 1.02)$ & $54.7( \pm 3.5)$ \\
Sand 0/4 & $13.61( \pm 0.82)$ & $58.5( \pm 6.2)$ \\
Tout-venant & $13.13( \pm 2.51)$ & $55.0( \pm 7.0)$ \\
Gravel 4/8 & $12.39( \pm 0.78)$ & $51.1( \pm 5.2)$ \\
Gravel 6/14 & $11.70( \pm 0.51)$ & $50.4( \pm 3.2)$ \\
Gravel 14/20 & $10.68( \pm 1.46)$ & $48.4( \pm 9.9)$ \\
Corundum & $11.88( \pm 1.75)$ & $48.7( \pm 5.8)$ \\
\hline
\end{tabular}

In brackets are the $95 \%$ confidence intervals

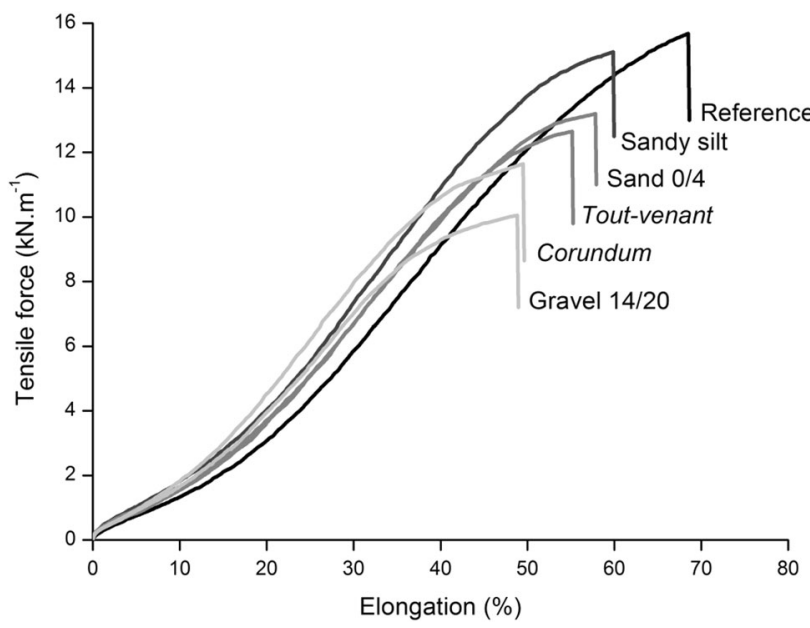

Fig. 3 Mean curves "tensile force-elongation" obtained for geotextile G250 before and after some mechanical damage tests 
The tensile strength of geotextile G250 decreased after the mechanical damage tests (from $16.00 \mathrm{kN} \mathrm{m}^{-1}$ for the undamaged sample to $10.68-15.57 \mathrm{kN} \mathrm{m}^{-1}$ after damage, depending on the soil used). Similarly, the elongation at maximum load was reduced from $70.4 \%$ for the reference sample to $48.4-60.8 \%$ after mechanical damage. The steeper slopes of the non-elastic region of the mean curves tensile force-elongation showed an increase in stiffness after the mechanical damage tests. The same consequence was observed for the curves not included in Fig. 3.

The reductions of tensile strength observed depended on the soil used in the mechanical damage tests. The tests performed with the finest soils (sandy silt and silty sand) caused no relevant modifications of the tensile strength (as the corresponding retained tensile strengths were $97 \%$ ). Oppositely, the elongation at maximum load decreased (from 70.4 to 59.3 and to $60.8 \%$, respectively). As the tensile strength remained practically unchanged (suggesting the inexistence of relevant damage in the nonwoven structure), the reductions of the elongation at maximum load may be due to the stretching induced by loading (which caused some pre-elongation in the specimens).

Both sands $(0 / 2$ and $0 / 4)$ caused a reduction in tensile strength of geotextile G250 (retained tensile strengths of 86 and $85 \%$, respectively) smaller than those due to confinement in the gravels (retained tensile strengths of 77,73 and $67 \%$ for gravels $4 / 8,6 / 14$ and 14/20, respectively). The tout-venant (retained tensile strength of $82 \%$ ) led to an intermediate reduction (between that of the sands and the gravels). However, the variability of the tensile strength was higher than for the remaining samples. The contact with corundum induced a tensile strength reduction of $26 \%$ (retained tensile strength of $74 \%$ ). This was identical to that with gravel $6 / 14$ and slightly lower than that with gravel 14/20 (still, relatively high dispersions were observed).

The mechanical damage tests with the sands, the gravels, the tout-venant and the corundum led to reductions of the elongation at maximum load. These reductions were not much different between the different soils (elongations at maximum load ranging from 48.4 to $58.5 \%$ ), yet seeming to exist a tendency for higher decreases in tensile strength (suggesting higher damage in the nonwoven structure) being followed by higher reductions in elongation at maximum load.

The reduction in tensile strength can be related with some grain size distribution parameters. The soils with bigger grain size $\left(D_{\max }\right)$ tended to cause higher decreases in tensile strength. The main exception was observed for toutvenant. Even though it had the highest $D_{\max }$, tout-venant was not the soil that caused the highest reduction in tensile strength, which may be due to its classification as a well graded soil. Indeed, it had a relatively high percentage of fine particles $(9.5 \%$ of the particles had a grain size lower than $0.074 \mathrm{~mm}$ ) and low amounts of large particles when compared to other soils (for instance, tout-venant had a $D_{60}$ lower the gravels and corundum). Thus, the damage that occurs during the mechanical damage test is likely to be influenced not only by the grain size, but also by the uniformity of the soil (poorly graded soils: $C_{U}<1$ and $1>C_{C}>3$; uniform soils: $C_{U}=1$; well graded soils: $\left(C_{U}>4\right.$ and $\left.1<C_{C}<3\right)$ ).

Tout-venant was a well graded soil with fewer voids than other uniform or poorly graded soils used. This means that the large particles were surrounded by small ones (less damaging), which created a larger contact area for the transference of stresses between tout-venant and geotextile G250 (a higher contact area leads to lower stresses at the surface of the geotextile). The previous discussion is obviously only valid when the soils are compacted.

The influence of soil uniformity can also be seen when comparing the damage caused by silty sand and sand $0 / 2$ (soils with relatively close grain sizes). Indeed, a higher reduction in tensile strength was found for the uniform soil (sand 0/2) (retained tensile strengths of 97 and $86 \%$ for silty sand and sand $0 / 2$, respectively). This difference may be, once again, explained by the higher contact area of the well graded soil (silty sand).

\section{Geotextile G400}

The defects observed visually in geotextile G400 after the mechanical damage tests were similar to those observed for geotextile G250. However, the fibre severing, the cuts, the bruising and the abrasion were less pronounced. This readily indicated a higher resistance of geotextile G400 against the induced damage.

Like for geotextile G250, the tensile properties of geotextile G400 also changed after the mechanical damage tests (Table 4). Indeed, the tensile strength (variation from

Table 4 Tensile properties of geotextile G400 after the mechanical damage tests

\begin{tabular}{lll}
\hline Soil & $T S\left(\mathrm{kN} \mathrm{m}^{-1}\right)$ & $E_{M L}(\%)$ \\
\hline Sandy silt & $25.08( \pm 0.31)$ & $61.1( \pm 4.7)$ \\
Silty sand & $24.71( \pm 2.17)$ & $55.4( \pm 3.8)$ \\
Sand 0/2 & $24.05( \pm 1.71)$ & $56.6( \pm 4.0)$ \\
Sand 0/4 & $24.02( \pm 1.76)$ & $52.7( \pm 5.2)$ \\
Tout-venant & $23.28( \pm 1.29)$ & $55.4( \pm 5.7)$ \\
Gravel 4/8 & $22.31( \pm 1.38)$ & $51.3( \pm 5.5)$ \\
Gravel 6/14 & $22.01( \pm 1.63)$ & $53.9( \pm 3.6)$ \\
Gravel 14/20 & $21.35( \pm 1.12)$ & $50.5( \pm 8.1)$ \\
Corundum & $21.48( \pm 1.03)$ & $53.9( \pm 6.2)$ \\
\hline
\end{tabular}

In brackets are the $95 \%$ confidence intervals 
25.56 to $21.35-25.08 \mathrm{kN} \mathrm{m}^{-1}$ ) and the elongation at maximum load (reduction from 70.9 to $50.5-61.1 \%$ ) tended to decrease. Figure 4 shows some mean curves tensile force-elongation obtained for geotextile G400 (certain curves were omitted for clarification purposes). These curves showed an increase in stiffness after the mechanical damage tests (this increase also occurred for the samples damaged with the soils omitted in Fig. 4).

The evolution of the tensile properties (after the mechanical damage tests) had a similar behaviour in geotextiles G250 and G400 (this way, the main conclusions withdrawn for geotextile G250 in "Geotextile G250" section are also valid for geotextile G400). However, and with exception for the finest soils (where no relevant changes occurred), the reductions in tensile strength were less pronounced for geotextile G400 (Fig. 5). The higher mass per unit area (and thickness) was responsible for the better resistance of geotextile G400 against mechanical damage.

\section{Reduction Factors for Mechanical Damage}

The reduction factors presented in this paper were determined from mechanical damage laboratory tests and thus should not be used for design. Nevertheless, they can be useful to compare the influence of the type of soil and the mass per unit area on the damage suffered by the geotextiles. Figure 6 illustrates the variation of $R F_{M D}$ with the $D_{50}$ of the soils used in the mechanical damage tests for geotextiles G250 and G400.

Geotextiles of the same product family with different values of mass per unit area have different robustness. Higher robustness resulted in lower values for the reduction factor, $R F_{M D}$. Generally, the soils with higher values of $D_{50}$ led to larger reduction factors. However, as the soils used

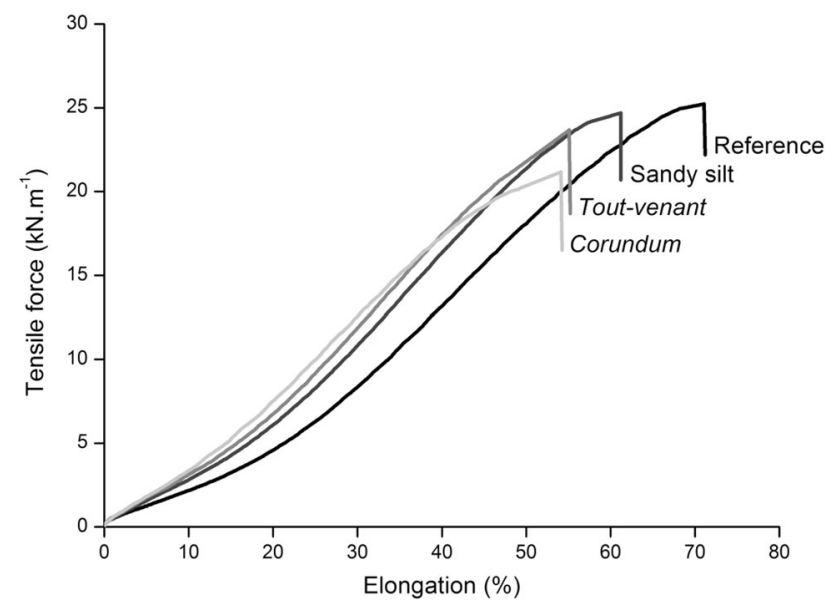

Fig. 4 Mean curves "tensile force-elongation" obtained for geotextile G400 before and after some mechanical damage tests

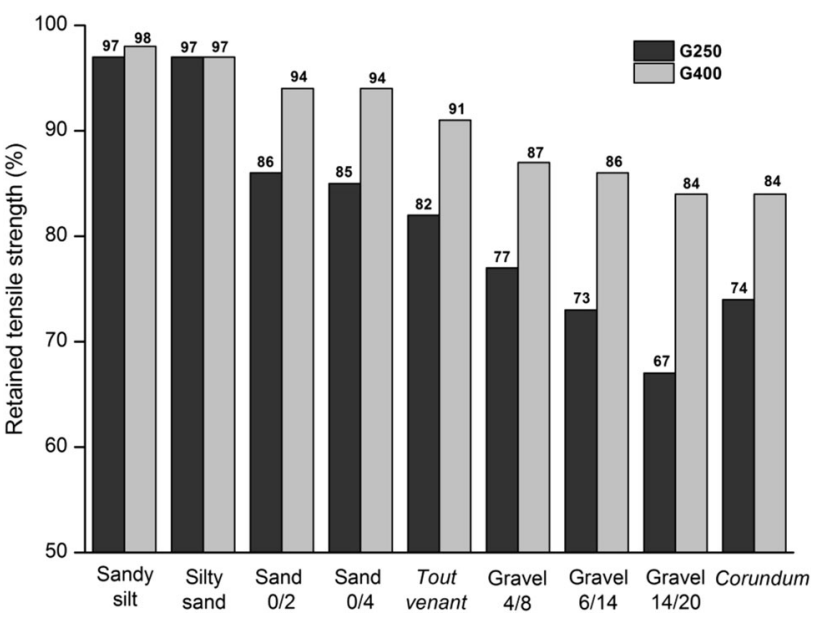

Fig. 5 Retained tensile strength of geotextiles G250 and G400 after the mechanical damage tests

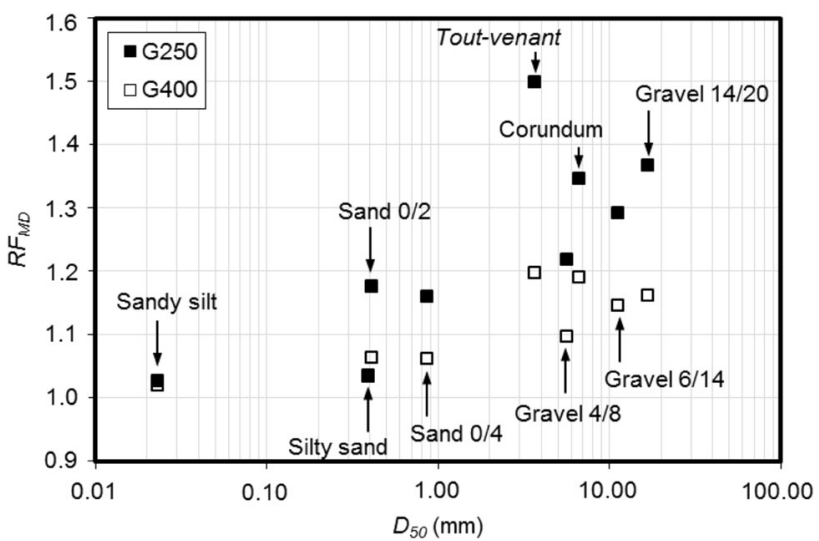

Fig. 6 Variation of $R F_{M D}$ with the $D_{50}$ of the soils for geotextiles G250 and G400

were quite different, there are other factors to be considered. The uniformity of the soils also played an important role on the changes observed after the mechanical damage tests. Soils with wider range of particle sizes seemed to be less aggressive.

\section{Conclusions}

The laboratorial mechanical damage tests (carried out with different types of soils) caused important changes in the tensile properties of two nonwoven geotextiles (G250 and G400) with different masses per unit area. The defects provoked included: fibre severing, cuts, bruising, abrasion and stretching. The stretching of the geotextiles occurred mainly for the soils with lower bearing capacities (which suffered considerable settlements during the mechanical damage tests, inducing permanent strains to the geotextiles). 
The laboratory mechanical damage tests led to reductions in tensile strength (main exception for the tests with sandy silt and silty sand). These reductions depended on the grain size and uniformity of the soils and on the mass per unit area (and thickness) of the geotextiles. The soils with larger grain sizes tended to cause higher decreases in tensile strength, while the soils with higher amounts of fines led to lower reductions. For soils with comparable grain size (such as silty sand and sand $0 / 2$ ), the decrease in tensile strength was higher for the uniform one (sand $0 / 2$ ). The reductions in tensile strength were lower for the geotextile with higher mass per unit area, G400 (exception for the tests with sandy silt and silty sand, where no relevant changes occurred in the tensile strength of both geotextiles). Additionally, the mechanical damage tests also caused changes in other tensile properties (decrease of elongation at maximum load and increase of stiffness).

The corundum (synthetic aggregate considered in EN ISO 10722 [11]) caused a higher reduction for the tensile strength of the geotextiles than most of the other soils used in the mechanical damage tests. This indicated that the use of corundum in EN ISO 10722 [11] may be a conservative approach for nonwoven geotextiles applied in fine soils. However, it could be below the safety limits when coarser soils are used. The previous conclusions are only taking into account the geotextiles and soils used in this work and cannot be generalized for other soils/geosynthetics. For that purpose, further research is needed.

Acknowledgments The authors acknowledge the financial support of "FCT_Fundação para a Ciência e a Tecnologia". José Ricardo Carneiro would also like to thank FCT for his research Grant (SFRH/ $\mathrm{BPD} / 88730 / 2012)$.

\section{References}

1. Koerner RM (1999) Designing with geosynthetics. Prentice-Hall, Upper Saddle River, NJ, USA, p 761

2. Pinho-Lopes MJF, Lopes ML (2010) Durability of geosynthetics. FEUP, Porto, Portugal, p 249 (in Portuguese)

3. Shukla SK (2011) Fundamentals of geosynthetics. In: Shukla SK (ed) Handbook of geosynthetic engineering, 2nd edn. ICE Publishing, London, pp 1-54

4. Allen TM, Bathurst RJ (1994) Characterization of geosynthetic load-strain behavior after installation damage. Geosynthet Int 1(2):181-199
5. Elvidge CB, Raymond GP (1999) Laboratory survivability of nonwoven geotextiles on open-graded crushed aggregate. Geosynthet Int 6(2):93-117

6. Watn A, Chew SH (2002) Geosynthetic damage-from laboratory to field. Keynote lecture. Proceedings of the $7^{\text {th }}$ international conference on geosynthetics, Nice, France, vol 4, pp 1203-1226

7. Hufenus R, Ruegger R, Flum D, Sterba IJ (2005) Strength reduction factors due to installation damage of reinforcing geosynthetics. Geotext Geomembr 23(5):401-424

8. Bathurst RJ, Huang B, Allen TA (2011) Analysis of installation damage tests for LRFD calibration of reinforced soil structures. Geotext Geomembr 29:323-334

9. ISO/TR 20432:2007 (2007) Guidelines for the determination of the long-term strength of geosynthetics for soil reinforcement. International Organization for Standardization

10. ENV ISO 10722-1:1998 (1998) Geotextiles and geotextile-related products - procedure for simulating damage during installation-part 1: installation in granular materials. European Committee for Standardization

11. EN ISO 10722:2007 (2007) Geosynthetics. Index test procedure for the evaluation of mechanical damage under repeated loading. Damage caused by granular material. European Committee for Standardization

12. Huang C-C (2006) Laboratory simulation of installation damage of a geogrid. Geosynthet Int 13(3):120-132

13. Huang C-C, Chiou S-L (2006) Investigation of installation damage of some geogrids using laboratory tests. Geosynthet Int 13(1):23-35

14. Huang C-C, Wang Z-H (2007) Installation damage of geogrids: influence of load intensity. Geosynthet Int 14(2):65-75

15. Pinho-Lopes M, Lopes ML (2013) Tensile properties of geosynthetics after installation damage. Environ Geotech 1(EG3):161-178

16. EN ISO 9862:2005 (2005) Geosynthetics. Sampling and preparation of test specimens. European Committee for Standardization

17. Lopes MP, Lopes ML (2003) Equipment to carry out laboratory damage during installation tests on geosynthetics. Geotecnia (Journal of the Portuguese Geotechnical Society) 98:7-24 (in Portuguese)

18. ISO/TS 17892-4:2004 (2004) Geotechnical investigation and testing. Laboratory testing of soil. Part 4: determination of particle size distribution. International Organization for Standardization

19. EN ISO 10319:2008 (2008) Geosynthetics. Wide-width tensile test. European Committee for Standardization

20. Montgomery DC, Runger GC (2010) Applied statistics and probability for engineers, 5th edn. Wiley, New York, p 784

21. EN ISO 9864:2005 (2005) Geosynthetics. Test method for the determination of mass per unit area of geotextiles and geotextilerelated products. European Committee for Standardization

22. EN ISO 9863-1:2005 (2005) Geosynthetics. Determination of thickness at specified pressures. Part 1: single layers. European Committee for Standardization

23. ASTM D2487-11 Standard practice for classification of soils for engineering purposes (unified soil classification system). American Society for Testing and Materials 